\title{
Origens do Estado do Grão-Pará e Maranhão e a política pombalina: discursos e relações de poder
}

\section{Origins of the States of “Grão-Pará e Maranhão" and the pombaline policy: discourses and power relations}

Alberto Damasceno - Professor Titular da Universidade Federal do Pará (UFPA). Doutor em Educação pela Pontifícia Universidade Católica de São Paulo (PUC). E-mail: albertod@ ufpa.br

Joaquina Ianca Miranda - Graduanda do curso de Licenciatura Plena em Pedagogia pela Universidade Federal do Pará (UFPA). Bolsista de Iniciação Científica - PIBIC/UFPA. E-mail: joaquinaianca@gmail.com

\section{Resumo}

Trata das origens do Grão-Pará e Maranhão, com ênfase no período pombalino. Busca compreender como se deu a organização territorial, econômica e política para a origem deste Estado, e qual a relação com os ideais pombalinos. Analisa, para o traçar dos fatos históricos, as "Instruções regias, públicas e secretas..." e o "Directorio..." dirigidas ao governador Mendonça Furtado, além do "Discurso economiástico", de autoria de José Gonçalves de Fonseca, caracterizando esta pesquisa como documental. Perpassa pela relação entre os religiosos e o governo do Estado, e discute sobre os embates que permearam o governo de Mendonça Furtado. Conclui que a origem desse Estado se assenta sobre ações governamentais de três eixos, intensificada com o advento do governo mencionado: povoamento; estímulo à agricultura e ao comércio; e controle direto do Estado que se derivou de uma conturbada relação entre os governantes, religiosos, intermediários, índios e indivíduos de mocambos.

\section{Palavras-chave}

Grão-Pará e Maranhão. Mendonça Furtado. Período Pombalino. Brasil Colônia.

\begin{abstract}
It deals with the origins of Grão-Pará and Maranhão, with an emphasis on the Pombaline period. It seeks to understand how it gave territorial, economic and political organization to the origin of this State, and what is the relationship with the Pombaline ideals. Analyze, to track historical facts, such as "Instructions for Regions, Publications and Secrets ..." and the "Directory ..." directed by Governor Mendonça Furtado, in addition to the "Economic Speech", by José Gonçalves de Fonseca, featuring this research as documentary. Cross the relationship between the religious and the state government and discuss those that allow the government of Mendonça Furtado. He concluded that the origin of this State is based on actions related to three axes, intensified with the advent of the mentioned government: settlement; stimulating agriculture and trade; and direct control of the state that derives from a suburban relationship between government officials, religious, intermediaries, indices and individuals from hovels.
\end{abstract}

\section{Keywords}

Grão-Pará e Maranhão. Mendonça Furtado. Pombaline period. Colonial Brazil. 


\section{INTRODUÇÃO: BREVES RELATOS DE SEU SURGIMENTO COMO ESTADO}

A Amazônia colonial portuguesa contava, na segunda metade do século XVII, com 10 capitanias: Maranhão, Grão-Pará, Ceará, Cametá, Alcântara, Caeté, Cabo do Norte, Piauí, São José do Rio Negro e Marajó. Embora Avellar (1970) indique a existência de 11 capitanias, a capitania do Xingu nunca saiu do papel e a do Cabo do Norte deixou de existir ainda naquele século. Devido à imensidão da área a ser administrada, na perspectiva da política mercantilista, e às dificuldades de acesso a partir do Brasil, após os primeiros anos de sua ocupação, ela foi separada do "Estado do Brasil" e, em 13 de junho de 1621, passou a ser um segundo Estado português no continente: o Estado do Maranhão ${ }^{1}$, criado por Filipe II. Tal iniciativa visava à consolidação do controle ibérico no delta do rio Amazonas e no norte da região.

A cidade de Belém passou a ser a base de inúmeras expedições ao interior do continente. Posteriormente, no período compreendido entre 1627 e 1632, diversas capitanias foram criadas no novo estado do Maranhão e Grão-Pará por Felipe III, visando estimular ações individuais de expansão do território (MAURO, 1991). Em 1652, o Brasil volta a ser um só Estado, mas, dois anos depois, Portugal recria o outro Estado do Norte, agora denominado Maranhão e Grão-Pará. Finalmente, em 1751, torna-se o Grão-Pará e Maranhão, com capital em Nossa Senhora de Belém.

As dinâmicas de interiorização, a organização de expedições com objetivos de obter trabalhadores indígenas, livres ou escravos, começaram a se intensificar no período [...] de 1650 a 1700, quando assistimos a uma consolidação do domínio português na região. Nesse momento podemos prontamente falar em contatos sistemáticos: guerras, resgates, descimentos, aldeamentos, escravidão, doenças, epidemias. Expedições oficiais anuais, além das incontáveis expedições particulares legais ou ilegais, rumo ao sertão do rio Amazonas, em busca de índios para serem comprados ou simplesmente capturados e escravizados (DIAS; BOMBARDI; COSTA, 2020, p. 11).

Foi em 1751 que o governo "abriu novas perspectivas de colonização para a região amazônica e para uma unidade administrativa encarada a partir de então como uma 'nova colônia', ou ainda, como um 'Estado nascente"' (SANTOS,

\footnotetext{
Este território era composto pelos estados hoje denominados: Ceará, Maranhão, Pará, Amapá e Amazonas (assim como alguns estados circunvizinhos a eles). Primeiramente denominado "Maranhão", depois "Maranhão e Grão-Pará" e posteriormente "Grão-Pará e Maranhão", este estado da América portuguesa se constituiu em unidade administrativa autônoma separada do Estado do Brasil. Compreendendo uma região que hoje se aproxima dos territórios dos estados citados anteriormente, esta segunda possessão portuguesa foi criada em 1621 e perdurou até 1772, existindo, portanto, durante pouco mais de um século e meio.
} 
2008, p. 59), intensificando as atividades econômicas e exploração agrícolas já existentes no período pré-pombalino, assim como fixando uma forte política de aldeamentos que será inculcada nas povoações pré-existentes.

A partir da década de 1750, com o governo pombalino, mudou-se a forma de incorporar os índios à sociedade colonial. Embora tenha sido utilizado o mesmo modelo dos aldeamentos para organizar as novas vilas, introduziu-se uma série de modificações nas modalidades de obtenção de trabalhadores. Os índios foram declarados livres, o que quer dizer que as tropas de resgate foram proibidas, permaneceram apenas as ilegais, cujos números não podemos contabilizar. A partir do governo pombalino, portanto, não há mais registros de escravos indígenas. Aconteceu ainda uma transformação na estrutura do trabalho, pois foi o momento quando efetivamente foram introduzidos escravos africanos na região em quantidade nunca vistas e a proporção entre eles e os índios passou a ficar mais equilibrada no conjunto da população trabalhadora (DIAS; BOMBARDI; COSTA, 2020, p. 12).

Ao mesmo tempo em que, do ponto de vista militar, se impunha a PAX colonial portuguesa, paralelamente, tornava-se imprescindível a inculcação dos valores da civilização ocidental cristã nos nativos da região, a partir de uma visão eurocêntrica do mundo, através da catequese levada a efeito pelos religiosos.

O modo de pregar destes missionários é com o evangelho em uma mão e com as leis de sua majestade em outra; porque tem mostrado a experiência que só na confiança do bom tratamento, que nas ditas leis se lhes promete, e na fé e crédito que dão aos religiosos da Companhia, se atrevem as ditas nações a sair dos matos, onde geralmente os tem retirado a lembrança e temor das operações passadas, crendo até agora que o patrimônio das ditas leis e dos ditos padres os defenderiam das ditas opressões [...] (VIEIRA, 1992, p. 57).

Era notória a forte influência dos religiosos sobre os índios, uma vez que "o trabalho indígena foi empregado em diferentes contextos, tempos e espaços americanos, antes e durante a adoção da escravidão africana como principal motor da produção econômica" (DIAS, 2019, p. 240). Mendonça Furtado, em carta a seu irmão, confirma o poder dos religiosos sobre os nativos que "[...] não tinham liberdade em coisa alguma, até os casamentos são a arbítrio dos padres [...], há de ser com aquela que lhes nomear o padre missionário, ainda que aliás seja contra sua vontade" (MENDONÇA FURTADO, 1963, tomo I, p. 70). De acordo com Souza Júnior (2012, p. 1), havia uma "acirrada disputa entre missionários, principalmente jesuítas, colonos e autoridades coloniais, pelo controle do trabalho indígena" em que espaços privilegiados, como a Junta das Missões, constituíram-se em espaços de controle deste trabalho. 
As políticas reformistas que D. José I, Carvalho e Melo implementaram, em relação ao trato com os indígenas na Amazônia colonial, compreendiam três grandes fatores intrinsecamente ligados à empreitada da colonização: a ocupação através de povoamento planejado; a exploração agrícola e penetração mercantilista; e o controle direto do Estado, não mais com a mediação dos religiosos, que deixaram de deter o poder temporal das aldeias.

[...] entre 1757 e 1798, os esforços da administração portuguesa na região para executar, minimamente, as disposições do projeto pombalino, passariam pelo reforço militar às áreas de "soberania duvidosa" e pelas inúmeras tentativas de consolidar tanto a produção de alimentos quanto a coleta de drogas do sertão, pelo estabelecimento das populações indígenas através dos descimentos ${ }^{2}$ nas povoações, garantindo as fronteiras e a necessária mão-de-obra à sustentação da economia colonial (SAMPAIO, 2003, p. 83).

Reformas no povoamento, estímulo à agricultura e ao comércio e controle direto do Estado. É sobre esses três eixos que vão se assentar as ações governamentais para a formação do "Grão-Pará e Maranhão" a partir de meados do século XVIII.

\section{A ORgANIZAÇÃo TERRITORIAL, ECONÔMICA E POLÍTICA DO ESTADO}

A organização política vigente no período anterior ao Diretório instituído no Governo de Mendonça Furtado era normatizada pelo Alvará de 7 de junho de 1755, que aboliu a administração temporal dos padres e atribuiu o governo das aldeias aos índios "principaes". Aldeias maiores, elevadas à categoria de Vilas, eram governadas por juízes ordinários, tinham vereadores e oficiais de justiça que, com a vigência do Diretório, a partir de 1758, passam a se submeter aos Diretores. A definição e regularização das fronteiras e limites dos territórios portugueses e espanhóis na América, em especial na Amazônia, eram também preocupações prioritárias. No entanto, este documento acaba:

[...] retomando o mesmo modelo do Regimento das Missões, o Diretório substituiu o missionário pelo diretor como agente responsável da administração do que antes eram missões e passaram a ser chamadas de vilas. Porém, no plano econômico e com relação ao regime de trabalho, adotou os mesmos princípios do Regimento das Missões de 1686, procurando aprimorá-lo, por meio da institucionalização do comércio do

Sobre os descimentos e seu impacto na demografia do Estado, consultar Dias, Bombardi e Costa (2020). 
sertão: padronizando os procedimentos de envio das canoas de coleta dos gêneros da floresta, regularizando a participação nas expedições, adotando medidas para reduzir contrabando e práticas de trabalho ilegais etc. (DIAS, 2019, p. 244).

Em 1753, Mendonça Furtado recebe do rei plenos poderes para tratar da questão dos limites na região, constituindo-se Primeiro Comissário para as conferências e demarcações. Devido à sua participação na Comissão de Limites, encarregada de delinear as fronteiras lusas na América, parte, em 2 de outubro de 1754, para o Rio Negro juntamente com vários especialistas estrangeiros enviados de Lisboa sob os auspícios do governo português, devido à ausência de técnicos capazes de compor turmas de campo.

Reiterando um conjunto de estratégias coloniais, as fronteiras do Rio Negro passariam a conviver, de forma mais sistemática a partir da segunda metade dos Setecentos, com a instalação de fortificações e a criação/ revitalização de novos estabelecimentos coloniais. A implantação de um governo na região, subordinado a Belém, fazia parte de um conjunto de ações administrativas com forte caráter estratégico-militar e, até o final da administração pombalino, serão construídos na região vários fortes que cobrirão as áreas de fronteira (REIS, 1993, p. 57-58 apud SAMPAIO, 2003, p. 82).

Após essa viagem, em que conheceu, fiscalizou, registrou e exerceu as atribuições a que tinha direito nas aldeias sob sua jurisdição, retornou a Belém, de onde sairia novamente em 16 de janeiro de 1758, já com o intuito de instalar as novas unidades administrativas, transformando as "Aldeias" em "Lugares" ou "Vilas", de acordo com o tamanho de sua população, e lhes dando nomes previamente escolhidos e designando os missionários como agentes desta implantação:

[...] porém, os aldeamentos formados se constituíam em realidades problemáticas porque esses missionários pouca experiência tinham no trato das missões, se comparados aos jesuítas. Além de tudo, estavam muito envolvidos nos negócios do sertão e até mesmo no tráfico ilícito dos índios (SAMPAIO, 2003, p. 76).

Vale dizer que, a partir desse momento, as povoações, cujos nomes eram predominantemente indígenas, passam a ter denominações de cidades portuguesas, conforme carta de sua autoria, enviada ao rei em 13 de junho de 1757, portanto, ainda anterior à sua segunda expedição. Havia também uma preocupação do governador com o processo de implantação radical da língua portuguesa na região, claramente expressa no seu "Diretório" de 1757, processo que os religiosos não se interessaram em deflagrar, o que se transformaria em um dos fatores justificadores de sua expulsão. 
Além das localidades originárias das tribos, das aldeias missionárias e da sede do governo, no estado do Pará, havia os mocambos, para onde fugiam e se organizavam comunitariamente os índios e negros escravizados ou insatisfeitos com a vida urbana ou aldeada. Com uma organização social complexa e uma estrutura produtiva dinamizada pelas próprias circunstâncias geradas pela clandestinidade e necessidade de sobrevivência, os mocambos mantinham relações econômicas com outros segmentos e setores da sociedade colonial. No que se refere à tentativa de aldeamento nos mocambos, "nem sempre a fixação nessas comunidades mocambeiras era definitiva e algumas delas também podiam ser refratárias a novas práticas de descimentos", que se constituíam como:

[...] uma estratégia destinada a ampliar as povoações e consistia no estabelecimento sistemático de contatos e acordos entre lideranças indígenas e agentes coloniais que culminavam com o deslocamento das populações de suas aldeias para estabelecer-se na vila colonial (SAMPAIO, 2003, p. 77).

Marcados por estes conflitos, os administradores recorriam a um conjunto de práticas coloniais para gerenciar e acomodar estes mocambos: "o recurso à catequese, o emprego da força e das justiças, o estímulo à hierarquização interna das populações através de uma política de distinções e privilégios às lideranças indígenas" (SAMPAIO, 2003, p. 83). Marcando esta população, ainda neste período de subordinação militar, ideológica e econômica, como agentes de resistência ao processo de colonização.

As atividades econômicas dos mocambos iam dos roubos a fazendas locais até uma intensa produção agrícola, passando, inclusive, pela exploração do minério de ouro. O resultado dessas iniciativas era a troca desses produtos, fosse em feiras livres ou no mercado clandestino, por aquilo que não era produzido nos mocambos, principalmente, alimentos, armas e munições. Em um estudo no qual se apresenta uma série de relatos sobre a participação de quilombos e mocambos em "redes comerciais clandestinas" no século XIX, Gomes (1993) conclui que:

As relações econômicas mantidas pelos habitantes dos mocambos eram freqüentemente complexas e sofisticadas. Nesse sentido, a simples caracterização dessas práticas econômicas como "dependentes" e/ou "parasitárias" não ajuda muito a entender a formação dos quilombos brasileiros. Os quilombolas procuravam, na medida do possível, obter maior autonomia e controle sobre suas vidas. Nessa busca, eles, inclusive, se engajaram em lutas políticas com dimensões amplas, nas quais eram feitas, desfeitas e refeitas alianças com outros grupos sociais (GOMES, 1993, p. 63-64). 
Há registros de que, em torno de Belém, praticava-se o cultivo da cana-deaçúcar. Eram vários os engenhos e fabriquetas destinadas à produção de cachaça. Sebastião e Melo estimularam a lavoura espalhando colonos portugueses pelas aldeias em um processo de mesclagem cultural. Foram incentivadas as culturas de cacau, anil, café, algodão, arroz e cravo, porém, cabe destacar que os incentivos à economia datam do final do século XVII, quando passou a haver uma expansão considerável da distribuição de terras e o incremento do cultivo do cacau, medidas que antecederam a gestão de Mendonça Furtado e foram intensificadas na mesma. Desse modo, visando ao desenvolvimento da agricultura, Melo apoiou a agricultura familiar, patrocinando a migração de colonos de várias regiões do império luso para o Grão-Pará. Alguns autores falam de um certo sucesso inicial dessa política; entretanto, a experiência não obteve o êxito desejado, devido a diferentes fatores que iam desde a adversidade das condições ecológicas até as grandes distâncias e epidemias (LINHARES, 1990).

A partir do advento da Companhia Geral de Comércio, segundo o historiador Manuel Nunes Dias, percebe-se uma conjuntura mais favorável em relação à economia do Estado. Defensor entusiasta da dita Companhia, criada por Pombal em 1755, Dias argumenta exaustivamente sobre a necessidade sentida àquela época de articulação entre o comércio e a segurança militar, no que tange à defesa do patrimônio ultramarino da Coroa portuguesa. Diz ele: "Na segunda metade do século XVIII o ponto saliente da política ultramarina da Coroa residia, com efeito, na predominância da defesa da Amazônia brasileira. A segurança e regularidade do giro mercantil exigiam, porém, o estabelecimento de fortalezas" (DIAS, 1970, p. 13). Entretanto, esta iniciativa apresentava dificuldades:

A defesa do patrimônio, isto é, a preservação das colônias, é, evidentemente, na ordem lógica, a primeira tarefa que enfrenta sempre uma metrópole colonizadora. O que, no caso português, e em especial em relação ao Brasil, tornava essa manutenção territorial um problema, era, de um lado, a defasagem que acima assinalamos no ritmo de desenvolvimento econômico da metrópole em relação às principais potências européias; de outro lado, a desproporção entre a imensidão dos domínios e a pequenez da metrópole (NOVAIS, 1983, p. 136).

Por outro lado, a importância que tinha a questão da segurança não encontrava eco junto às autoridades da metrópole. No que tange à defesa militar do Estado, a situação era crítica, pois o poder bélico do Grão-Pará e Maranhão não era nada bom. "Deviam-se meses de sôldo às tropas. Os fortes estavam em ruínas. Soldados indisciplinados e oficiais decrépitos não mereciam confiança: viviam eslazeirados e famintos" (DIAS, 1970, p. 35-36). O próprio Mendonça 
Furtado denuncia, em 1751, a desmoralização do serviço militar no Grão-Pará, afirmando que achou "nestas terras introduzido um tal ódio ao serviço militar que, antes qualquer sujeito quer exercer a ocupação mais vil que sentar praça de soldado" (MENDONÇA FURTADO, 1963, tomo I, p. 60).

Após 1775, mais precisamente, a partir da implantação da Companhia Geral do Comércio, consolidam-se mudanças no quadro demográfico. Se, para Dias (1970), elas foram positivas, na medida em que “[...] condensaram-se, progressivamente, os grupos demográficos das baixadas amazônica e maranhense, forças sociais animadoras do povoamento de certas áreas do interior ignato e da orla atlântica" (DIAS, 1970, p. 58), para outros autores, o que acontece é um processo de conversão do gentio, de índio tribal para índio genérico; nas vilas e lugares criados na era pombalina, ocorre a transformação deste índio tribal ou genérico em força de trabalho, fenômeno que, ainda na fase do governo temporal dos religiosos, já recrudescia (MOREIRA NETO, 1988, p. 24-25).

A verdade é que a temática do povoamento - leia-se, por consequência, a mão-de-obra - foi objeto de lutas entre colonos, nativos e religiosos (em especial, os jesuítas, mas não apenas estes) na Amazônia colonial, as quais redundaram na expulsão destes últimos (ver SOUZA JÚNIOR, 2012). Daí ser necessário verificarmos como, e em que proporções, se desenvolveu este conflito.

\section{2 "COMPANHIA MERCENÁRIA": A RETALIAÇÃO RÉGIA CONTRA OS JESUÍTAS}

Para Domingues (2019), à medida que os religiosos se voltam de maneira oposta ao projeto pombalino de reformas e renunciam ao poder temporal e espiritual sobre a população indígena, o controle pleno sobre as pessoas, almas e do seu valor indígena enquanto mão de obra, aqueles tornaram-se num dos principais alvos da política de Mendonça Furtado ocasionando sua expulsão do território amazônico ou os designando a tarefas restritas à evangelização. Havia um discurso fervoroso de acusação dos religiosos pela ruína do Estado, proferido por Mendonça Furtado, mas o que de fato se observa é que o GrãoPará e Maranhão se tratava “[...] de um estado no qual o controle da força-detrabalho permitiu aos religiosos ocuparem os principais setores produtivos e, por conseguinte preponderar sobre o comércio, prejudicando a arrecadação fiscal" (OLIVEIRA, 2006, p. 133) por parte do Estado. Nesta medida, àquela altura:

[...] o Estado do Grão-Pará e Maranhão possuía sua economia apoiada no uso do trabalho compulsório dos índios que estava, até aquele momento, sob controle dos missionários. Na aplicação das novas disposições políticas, 
ganhou importância estratégica a expulsão dos religiosos regulares que controlavam as prósperas aldeias missionárias. Essa medida foi tomada após a secularização das missões e a declaração da lei de "Liberdade dos Índios” em 1755 (SAMPAIO, 2003, p. 79).

Conforme Domingues (2019), é neste momento que as ordens religiosas passam a ter papel fundamental nos assentamentos, pois constituíram verdadeiras redes de povoamento - indispensáveis à ocupação e exploração daquele território denominadas de Missões, que eram "igualmente pontos de partida e de apoio às atividades que os missionários realizavam, no sentido de persuadir as populações indígenas aos 'descimentos', e foram uma das causas do imenso poder económico detido pelas ordens religiosas no norte do Brasil" (DOMINGUES, 2019, p. 139).

Apesar das dificuldades de relacionamento com as "religiões", Mendonça Furtado cuidava de zelar pelos "bons costumes" da sociedade local. Em janeiro de 1757, o governador baixaria um Bando ${ }^{3}$ proibindo a abertura de tavernas durante as Ave-Marias e à noite "sob pena de prisão de 24 horas para o proprietário que durante esse tempo ficaria na golilha (argola pregada em um poste, à qual se prendia alguém pelo pescoço), pegando ainda 15 dias de calabouço e multa de $12 \$ 000$ réis destinada aos hospitais" (LAPA, 1978, p. 30).

Passados poucos meses, entretanto, em 8 de outubro de 1757, D. José I enviou ao Papa Benedicto XIV, por meio de seu ministro em Roma, Francisco de Almada de Mendonça, uma correspondência cujo conteúdo manifestava sua preocupação com os conflitos ocorridos entre o Estado português e a Ordem dos Inacianos. Logo no título da citada correspondência, o rei menciona o norte da América portuguesa (referindo-se ao estado do Grão-Pará e Maranhão) como um dos focos de "desordens" por parte dos jesuítas, embora as aldeias missionárias não estivessem sob jurisdição religiosa apenas destes, mas também sob a atuação de outros religiosos, como os carmelitas:

Instrucção que Sua Magestade Fidelissima mandou expedir em oito de Outubro de mil setecentos cincoenta e sete a Francisco de Almada de Mendonça, seu ministro na Côrte de Roma, sobre as desordens que os Religiosos Jesuitas tinhão feito no Reino, e no Brazil, para as representar ao Santissimo Padre Benedicto XIV com a Relação abreviada dos insultos que os mesmos Religiosos havião feito no Norte e no Sul da America Portuguesa (COLLECÇÃO DA LESGISLAÇÃO PORTUGUESA..., 1829, p. 471).

O conteúdo, claramente voltado para a tentativa de convencer o Papa da suposta vileza dos Inacianos, fala da esperança régia na emenda de tantas desordens

Documento oficial equivalente a uma proclamação, ou a um pregão público. 
sem prostituir os filhos da Religião da Companhia, e expressa ainda o desprazer ante a absoluta corrupção destas províncias de Portugal, sob seus comandos. A reação contra a Companhia Jesuíta continuou a se desencadear e, em 15 de maio de 1758, Dom Francisco Cardeal Saldanha, Visitador e Reformador Geral da Companhia de Jesus nos Reinos de Portugal, dos Algarves e seus Domínios, baixa a determinação reiterando a proibição a "[...] todas as pessoas dedicadas ao Sacerdocio, macularem o seu Santo Ministerio, com a ingerencia nos negocios Seculares” (COLLECÇÃO DA LESGISLAÇÃO PORTUGUESA..., 1829, p. 543).

No documento, as inúmeras alusões ao envolvimento de religiosos com o comércio sugerem a ideia de grave pecado por parte dos padres, “[...] eccelesiasticos, que sem pejo da lição Evangelica, e sem temor de Deos, solicitavão, indecorosos interesses mercantis” (COLLECÇÃO DA LESGISLAÇÃO PORTUGUESA..., 1829, p. 543). Mandando que estes fugissem " [...] como de peste do Ecclesiastico negociante, que de pobre se fez rico, e de humilde, arrogante por tão illicito meio" (COLLECÇÃO DA LESGISLAÇÃO PORTUGUESA..., 1829, p. 543). As reprovações do visitador à intervenção de padres em transações terrenas são testemunhos do crescimento e expansão das atividades negociais.

[...] chegão à mais deploravel corrupção, de mandar buscar drogas aos Sertões, para depois as fazerem vender, de mandarem salgar carnes, e peixes para o mesmo fim, de mandar tambem salgar, e accumular coiros para negociarem, e até a terem dentro nas proprias Casas das suas residencias Tendas de generos molhados, ou de fazendas comestiveis, açougues, e outros officios sordidos, ainda a respeito dos mesmo Seculares da classe dos Plebeos (COLLECÇÃO DA LESGISLAÇÃO PORTUGUESA..., 1829, p. 547-548).

A apropriação de vastas áreas de terras no Estado é confirmada, embora sob outra ótica, por Serafim Leite, quando este trata da ocupação da ilha do Marajó (na época, ilha de Joanes) pelos jesuítas. Tal ocupação é caracterizada em três fases distintas - a terceira, referente à questão dos negócios da Companhia no Grão-Pará, ele denomina "econômica”, posto que acontece quando:

[...] a Vice-Província do Maranhão, procurava recursos não apenas para as necessidades da catequese, edifícios e vida corrente, mas também para a autonomia missionária a que tendia, buscando os meios de criar, educar e formar na própria terra os futuros missionários, obra que não poderia fazer-se sem avultados recursos: é o período das fazendas e criações famosas [...] (LEITE, 1943, p. 235-236).

São inúmeras as citações das empresas agropastoris dos jesuítas pelo próprio Serafim Leite (1943, p. 249): em 1653, encontrou algumas vacas na 
fazenda do Colégio de Nossa Senhora da Luz; em 1734, existiam seis fazendas (Santa Quitéria, Santo Cristo, São Miguel, Nossa Senhora do Rancho, Nossa Senhora do Marajó e a Fazenda dos Pobres, que aos pobres se destinava); o crescimento das propriedades exigiu seu agrupamento em dois grandes centros, a Fazenda do Marajó e a Fazenda do Arari; em 1759, a Fazenda do Marajó tinha 2.550 cabeças de gado vacum; mais ou menos, 72 cavalos de serviço; um lote de oito éguas com seus filhos; e 20 cabeças de gado suíno ao todo. Dias (1970, p. 178) confirma o fato de os jesuítas constituírem “[...] a Ordem mais prestigiosa e abastada de todas que missionaram no estado durante o período colonial". Não resta dúvida de que a Ordem enriqueceu bastante na região amazônica e que isto estimulou uma razoável antipatia por parte dos comerciantes portugueses em relação aos membros da Companhia. Era notável a força da Ordem dos Jesuítas, seja na expansão de suas obras e posses, seja no bojo da sua relação com os nativos, incluídas aí suas atividades educativas, caracterizadas como parte de um ambicioso e clandestino plano.

[...] hião a toda a força estabelecendo com quasi successivo progresso desde o Maranhão até o Uraguay, animando clandestinamente o grosso Commercio, e a fertil Povoação daquellas numerosissimas Colonias, pelos Collegios, Casas Professas, e residencia, que conservão nas duas Côrtes, e terras grandes dos lugares maritimos de ambos os Reinos, e seus Dominios, tenhão quasi fechado as duas Americas Portugueza, e Hespanhola, com um cordão tão fórte que dentro do espaço de dez annos, seria indessoluvel o nó que com elle pertendião apertar os referidos Religiosos, não havendo forças em toda a Europa que fossem bastantes, para o expugnar, de tão vastos Sertões defendidos por homens, no numero quasi infinitos, cuja lingua, e costumes só os mesmos Religiosos podião entender, e praticar; accrescendo o odio implacavel, em que os educavão, e endurecião irreconciliavelmente, contra todos os brancos Seculares (COLLECÇÃO DA LESGISLAÇÃO PORTUGUESA..., 1829, p. 547-548).

A vitória, ainda que parcial, dos religiosos, no que diz respeito à liberdade dos índios, trouxe importantes lucros políticos e, sobretudo, econômicos (pois estes acabaram monopolizando a mão-de-obra nativa). Entretanto, seria o início de sua derrocada como a ordem religiosa mais poderosa e atuante na região. A expulsão de 1759, embora a mais radical e definitiva, não foi a primeira experimentada pelos jesuítas: estes vivenciaram várias expulsões na América portuguesa. A primeira delas aconteceu no Rio de Janeiro a 13 de julho de 1640. O mesmo aconteceu em São Paulo, para onde retornaram apenas em 14 de maio de 1653. Em São Luiz, no ano de 1661, foram expulsos das aldeias dos índios e dos colégios e foram presos. Em Belém, a 17 de julho de 1661, o Colégio dos Jesuítas foi invadido e os padres (inclusive Antonio Vieira) foram presos. Um 
dos argumentos mais utilizados para seu desterro se prendia à fortuna acumulada pela Ordem, graças à manipulação gratuita da mão-de-obra indígena. Beozzo (1983) informa que:

[...] a introdução de escravos negros, prevista no Regimento das Missões de 1680, foi escassa em relação às necessidades; não alterou substancialmente as condições do mercado de mão-de-obra [...]. Com escrúpulo, no início, abertamente depois, a pretexto de sustento das missões, lançam-se as diversas ordens religiosas na lucrativa coleta e comércio das drogas do sertão. Isentas de impostos, não tendo dificuldades no recrutamento da mão-de-obra, disponível nas aldeias por elas administradas, tornaram-se as Ordens Religiosas as principais organizações econômicas do Maranhão e Grão-Pará (BEOZZO, 1983, p. 47).

Se a inveja de moradores e governantes por causa da visível prosperidade era real, não há como negar um certo desvio dos objetivos originais que levaram as Ordens a implantar suas obras naquele Estado. A instrução do trabalho feita aos povoadores, que se apoiava numa perspectiva de disciplina e de conhecimento da "cultura das terras", pode ser considerada como atividade patente de maior brevidade e cuidado para "O aumento da povoação", e ainda "também para a defesa de qualquer invasão” estrangeira (MENDONÇA FURTADO, 1963, tomo I, p. 208). Em face do aumento da terra, um problema comum se achava sedimentado na carência de índios. Esse problema, enfim, resultou no radical questionamento aos padres da Companhia, dimensionado para a neutralização dos descimentos de índios - artifício que adotavam as religiões, que iam, por sua vez, "engrossando as suas fazendas de escravos" (MENDONÇA FURTADO, 1963, tomo I, p. 212-213). Destruir os “padres mercenários” significava, portanto, uma vigência doutrinária, uma peça necessária de produção do trabalho nessas terras, cujo sentido era florescer as plantações, "aumentar o comércio" e evitar a "total ruína do estado".

Para criar a prosperidade na Amazônia seria essencial privar os jesuítas do "poder absoluto" que o controle da mão-de-obra indígena e a posição estratégica de suas missões lhes davam tanto no comércio, quanto no contrabando [...]. Um suprimento abundante de negros tornaria desnecessária a escravidão indígena, reduziria a influência jesuíta e proporcionaria a mão-de-obra indispensável ao trabalho da terra e ao desenvolvimento do comércio. $\mathrm{E}$ isto, por sua vez, aumentaria a arrecadação real e ajudaria a financiar o novo sistema defensivo e a garantir as fronteiras dos domínios portugueses (MAXWELL, 1995, p. 34).

O confronto entre o governo de Mendonça Furtado e os religiosos, tendo ao meio os indígenas, revelou-se um processo intricado e complexo, 
apresentando inúmeras facetas, assim como consequências trágicas para os nativos da região, pois, "o pomo de discórdia entre colonos e missionários não era a escravidão versus a liberdade, mas a definição de quem deveria exercer o controle sobre o trabalho indígena” (DIAS, 2019, p. 238, grifo do autor). Desta forma, "os jesuítas e missionários em geral eram vistos como uma ameaça, posto que desfrutavam de significativos poderes de persuasão, causando sérios riscos ao projeto pombalino" (GUZMÁN; RAIOL JUNIOR, 2019, p. 183).

Cada lado, evidentemente, aponta o outro como responsável pela miséria espiritual e material que ali grassava, e o resultado de suas posições, mais do que esclarecedor ou conclusivo, é parcial, esparso, emocional e profundamente ideologizado. As ações governamentais de Mendonça Furtado e sua "[...] tarefa de reconstruir o Pará e toda a jurisdição do Estado pode ser comparada à preparação de um terreno a ser cultivado. Era preciso remover as pedras e as ervas daninhas que impediam o florescimento do campo" (SANTOS, 2008, p. 62). Ao lado das questões de ordem moral, o governador salientava a dificuldade que havia em conseguir a mão-de-obra sob controle religioso, caracterizando este como um dos polos da discórdia entre o estado e a Igreja na região.

E pelo que respeita ao mantimento que eu podia esperar das aldeias, estou já bastantemente desenganado pelos padres, de que não poderei tirar delas coisa que me possa ajudar, porque os padres me dizem absolutamente que não podem obrigar os índios àquele trabalho [...] assim porque é contra os seus interêsses como para me desgostarem, porque êles sabem muito bem que eu lhes não sou propício às suas conveniências (MENDONÇA FURTADO, 1963, tomo II, p. 437-438).

Sua preocupação chega ao ponto de exigir uma rigorosa reforma, e sua crítica não atingia apenas aos jesuítas, senão outras Ordens: "Os capuchos, que no nosso Portugal conservam aquelas aparências de penitentes, aqui trocam inteiramente: vejo-os com botas calçadas e esporas, armados de espingardas, catanas e pistolas" (MENDONÇA FURTADO, 1963, tomo I, p. 144). Em uma carta datada de 26 de janeiro de 1754, Mendonça Furtado expõe longa e explicitamente sua insatisfação em relação às "Religiões" (como eram chamadas as Ordens religiosas). Se, de um lado, expõe a justeza das decisões reais e o respeito de administradores e ministros para com estas, de outro, lamenta a inteira indisciplina com a qual os padres (em especial, os jesuítas) as tratam:

Não sucederá assim à outra parte dessa República, que não teme nem as prisões, nem outro algum gênero de castigo, qual é aquêle corpo poderoso que absorveu em si, assim o comércio como os fundos das terras, monopolizando para as fábricas todos [os recursos] do país, não deixando de fora dêste monopólio nem ainda as artes fabrís e o alimento 
ordinário sem o qual não podiam subsistir os povos, o que tudo se acha recolhido das portarias das Religiões para dentro, como a V. Exa. tenho larga e administrativamente informado várias vêzes [...]. Êste corpo, não só poderosíssimo, mas formidável a êste estado, é o que nunca se pôde pôr em obediência, nem será possível consegui-lo enquanto se conservar o sistema presente [...] (MENDONÇA FURTADO, 1963, tomo I, p. 437-453).

\section{DE ALDEIAS A VILAS E LUGARES}

Se o início do Governo Mendonça Furtado no Grão-Pará e Maranhão tem como marco documental as "Instruções régias...", nas quais já constam referências aos religiosos, seu término pode ter como marco documental o "Discurso economiástico..."4, de autoria do Secretário do estado José Gonçalves de Fonseca. Nesse discurso, que se trata, na verdade, de uma tentativa de síntese histórica do governo de Mendonça Furtado, Fonseca resgata brevemente o processo de formação daquele Estado e disserta sobre os problemas do governador com os religiosos (principalmente os jesuítas), fazendo referências explícitas a excessos de padres na administração temporal de suas aldeias, retomando o tema dos conflitos entre Estado e Companhia de Jesus no Grão-Pará.

Após livre interpretação dos acontecimentos prévios ao governo de Mendonça Furtado, que serviram de "[...] breve e sucinto detalhe de turbulência que combatia e consternava aquela dilatada conquista" (MENDONÇA FURTADO, 1963, tomo III, p. 1209), o escriba passa então a narrar a chegada do irmão de Carvalho e Melo e seu desempenho à frente do grande Estado. "As expugnações que ocupavam todo o seu cuidado [...] são sintetizadas em dois objetivos principais do novo governador, quais sejam desalojar os Regulares do governo temporal dos índios aldeados, e libertar do poder dos moradores milhares dos outros índios” (MENDONÇA FURTADO, 1963, tomo III, p.1210-1211).

Fica, desse modo, comprovada a tese de que Mendonça Furtado já chegara ao Grão-Pará e Maranhão cônscio da tarefa de enfrentamento com os religiosos. O atencioso Secretário omitiu, entretanto, a questão da demarcação dos limites como objetivo importante de sua presença na região, pois era esta também uma estratégica missão a ele confiada.

As demarcações dos limites territoriais na parte norte do vale amazônico eram imprescindíveis para a coroa lusitana. Mas requereu um esforço

\footnotetext{
A denominação completa do documento é "Discurso Enconomiástico, em que, para melhor inteligência do seu contexto, se dá princípio pela situação dos estados do Grão-Pará, com notícia abreviada das suas povoações; e se descreve o sistema do seu governo antigo, que de presente foi abolido e retomado" (MENDONÇA FURTADO, 1963, tomo III, p. 1204).
} 
considerável para pôr em prática. [...] Para esta finalidade, era importante percorrer os mais diversos locais e rios da região e fixá-los aos domínios da Coroa. No tocante ao gerenciamento das funções, era importante nomear um chefe de confiança para comandar as tropas. Tais tropas teriam oficiais militares, astrônomos, geógrafos, capelães, cirurgiões, soldados e gente de serviço: um número considerável de pessoas. Portanto, é perceptível que as demarcações dos limites tinham um contingente expressivo de grupos indígenas a seu serviço, isto fica evidente num ofício encaminhado pelo Provincial do Carmo, padre José da Natividade, para o Diogo Mendonça, o conteúdo do ofício que ressalta a grande quantidade de índios cedidos para as demarcações nos rios Negro e Solimões (GUZMÁN; RAIOL JUNIOR, 2019, p. 185).

Narrando com tintas épicas a expedição que o governador fez ao sertão amazônico, Fonseca destaca a transformação das aldeias em vilas ou lugares, a mudança de seus nomes e o esforço em impor-lhes a língua portuguesa, denominada no texto de "idioma de vitoriosos". Ao lado da publicação da lei de 6 de junho de 1755, que concedia aos índios a liberdade geral, o discurso dá especial atenção à reação dos jesuítas: "Saíram como furiosos aos púlpitos e ali envolvendo nas doutrinas santas os incentivos do seu ódio detestável, deram a beber este veneno propinado com as verdades católicas à sinceridade dos fiéis no cálice da sua paixão" (MENDONÇA FURTADO, 1963, tomo III, p. 1226).

Fonseca trata do Diretório estabelecido pelo governador como o mais bem regulado sistema da vida civil daqueles povos e da sua aprovação pela lei. Prova inconteste da competência administrativa do fidalgo luso é o fato de que Francisco Xavier de Mendonça Furtado deixou o governo do GrãoPará e Maranhão "com 40 aldeias convertidas em vilas; e 23 em lugares, além de 4 vilas mais de que foi fundador, no Macapá, rio Negro, no Javari e rio da Madeira" (MENDONÇA FURTADO, 1963, tomo III, p. 1227), o que originou o surgimento das vilas e lugares, ou a transformação nestas, das antigas aldeias missionárias. É neste momento que os nomes indígenas de tais aldeias se transformam em denominações de cidades portuguesas.

Caeiro (1936) realizou uma resenha dos aldeamentos realizados pelos jesuítas, sumarizando 37 anos de descimentos, fundação e povoamentos, onde se observa a alteração dos nomes indígenas originais por nomes de vilas portuguesas. Nestas aldeias, segundo o autor, a fazenda real concorreu com alguma quantia para sua povoação, apesar do mesmo afirmar inicialmente que a Coroa não contribuiu com nada. Tal quadro, embora se choque com a afirmação de que "[...] os jesuítas financiaram nos primeiros séculos da história brasileira, com recursos próprios o sistema escolar e educacional por eles construídos" (BERGER, 1984, p. 197), nos dá uma ideia, ainda que incipiente, da gigantesca tarefa dos jesuítas, ainda 
mais quando se sabe da quantidade de recursos necessários para a implantação destes povoados.

Em uma reflexão acerca do trabalho jesuítico realizado ao norte da América portuguesa, Manuel Narciso Martins, tradutor da obra de Caeiro, faz uma oportuna comparação das aldeias do Estado do Grão Pará com as do sul do continente, chegando a uma conclusão surpreendente:

\begin{abstract}
Se olharmos por outra parte ao estado de umas e outras enquanto à sua vitalidade, verificamos que as do Paraguay estavam nos ultimos anos da sua existencia quasi estacionárias; ao passo que as do Pará-Maranhão se achavam cheias de vida e iam tomando um desenvolvimento tal que podemos computar em quatro ou cinco mil indios os que anualmente se agregavam ao seio da greja (sic), quando delas desterraram os missionários. Quanto ao numero das aldeias, ao serem extinctas as missões, sabemos que aquelas não iam alem de 30; emquanto as do Maranhão eram quasi o dobro, ou 55, espalhadas pelos matos do escoadouro do Amazonas e de outros rios (seus nomes podem ver-se no Atlas do P. Ludovicus Carrez, Paris). Por aqui se vê a importancia, que iam já tendo aquelas missões, a todos os respeitos admiraveis da Vice-Provincia do Maranhão em 1755. E se não fôra o estulto golpe descarregado por Carvalho contra eles, aquelas regiões feracissimas até levariam em breve vantagem a quaisquer outras do Brasil, e hoje em prosperidade se avantajariam mesmo às de $\mathrm{S}$. Paulo (CAEIRO, 1936, p. 499).
\end{abstract}

Cabe ressaltar que a criação de vilas na região Amazônica teve início a partir dos anos de 1750, “[...] dentro de uma política que visou substituir os antigos aldeamentos por vilas com uma deliberada conversão toponímica de substituição dos nomes indígenas dos lugares por nomes inspirados nos mais antigos municípios de Portugal" (COSTA, 2019, p. 122), porém, foi Mendonça Furtado que esteve à frente de boa parte da criação de vilas e lugares no Estado, sobretudo no ano de 1758.

No seu Diretório, Mendonça Furtado inicia com uma referência ao Alvará de 7 de junho de 1755, que aboliu a administração temporal dos religiosos sobre as aldeias indígenas e transferiu este poder aos seus Principaes (denominação utilizada para designar os líderes indígenas que passaram à função de governança). No entanto, por acreditar que os mesmos não seriam capazes de cumprir sua tarefa de educar e civilizar a aldeia, propõe a nomeação de um diretor que o faça de acordo com os objetivos determinados por seu governo, com a necessária anuência da Coroa portuguesa. Este diretor devia "[...] ser dotado de bons costumes, zelo, prudencia, verdade, sciencia da lingua, e de todos os mais requesitos necessarios para poder dirigir com acerto os referidos Indios debaixo das ordens" (DIRECTORIO..., 1829, não paginado). 
Quanto a essa administração, “as ações seriam mais incisivas e a figura dos Diretores - executores imediatos dessa política - teria um papel chave para mediar as relações entre os Principais, índios aldeados, colonos e a própria Coroa" (SAMPAIO, 2003, p. 84). Em contrapartida, nesta direção cabia aos Principais e aos oficiais das povoações as responsabilidades pela articulação dos descimentos, estratégia indispensável para ampliação demográfica das povoações (SAMPAIO, 2003).

Cabe ainda salientar que essa liderança indígena legitimada e institucionalizada nas ações legislativas do governo de Mendonça colocava estes líderes em um duplo dilema, isto é, seu:

$[\ldots]$ poder e a autoridade [...] enquanto intermediários entre os portugueses e os demais índios, dependia da sua capacidade de articular ou oscilar entre a satisfação dos intentos da política indigenista e os interesses dos índios seus liderados - não raro, ora satisfazendo uns, ora outros (ROCHA, 2020, p. 389).

Neste contexto, o diretório de 1757 se constituiu em uma norma abrangente, proibindo o uso da língua nativa, obrigando o uso de sobrenomes portugueses, impondo construções em estilo europeu, priorizando a agricultura de exportação e estimulando o comércio. Ao mesmo tempo “as localidades próximas ao mar ou rios deveriam dedicar-se às feitorias de salgas de peixe destinados ao comércio; naquelas onde havia disponibilidade de cacau, salsa ou cravo, os índios deveriam ser conduzidos para sua extração" (SAMPAIO, 2003, p. 84).

\section{NATIVOS E POBRES: OS OUTROS ATORES}

A primeira impressão que se tem ao estudar o período da segunda metade do século XVIII na Amazônia portuguesa é a de que existiam duas forças sociais em atuação divergente: o estado português e a Companhia de Jesus. Tal visão é turva e distante da verdadeira face política da região naqueles tempos. A exigência do cultivo da terra, uma política dirigida pelo governo Mendonça Furtado não apenas para a economia de subsistência, mas também como resposta administrativa às dificuldades de aldeamento, foi uma ação governamental de amplo interesse civilizatório do processo de trabalho e dos costumes socialmente vigentes, e, por muito tempo, esta tarefa era desempenhada por indígenas tidos como "inúteis".

Àqueles a quem Vieira chama de "inúteis", as mulheres, os velhos e as crianças (além da metade dos homens adultos que não haviam sido convocados para nenhuma expedição), ficava a tarefa de plantar os mesmos gêneros, de cujos dízimos se financiariam as expedições. As 
mulheres, crianças e os velhos eram, portanto, empregados na roça, na produção de aguardente, na produção agrícola das drogas do sertão, na produção de farinha, de algodão, no trabalho doméstico; as mulheres, ainda, como amas de leite, fiadeiras, artesãs. Produzindo nada menos do que farinha, algodão e aguardente, eram responsáveis pelo sustento, vestimenta e circulação de moedas (o algodão), além do pagamento aos remadores. Os meninos ajudavam no trabalho de conversão e no sacerdócio, e certamente se tornavam guerreiros e remadores quando mais velhos [...] além de coletores, pescadores, caçadores e intermediários do comércio do sertão (DIAS, 2019, p. 245).

Assim, a maior parte da população ali existente (os índios) corresponde diretamente às pretensões da ideologia lusa, na perspectiva de produzir um mundo que se expressa qualitativamente através da transformação da cultura dos "bárbaros", os quais - fossem eles livres ou escravos, "[...] maneiras de nomear sujeitos indígenas em razão do modo como haviam sido incorporados à sociedade e segundo o domínio de quem se encontravam" (DIAS, 2019, p. 246), - eram desmoralizados e desmobilizados em prol de um avanço social luso. Desmobilizados frequentemente para fora dos aldeamentos, tiveram limites físicos para manter as estruturas familiares. Se o tempo de ausência das aldeias no período missionário variava de seis a oito meses, sob a organização do Diretório, a tendência foi a transferência contínua de um lugar a outro e a imobilização nas frentes de trabalho, por períodos sempre superiores há um ano.

Pelos próximos seis a oito meses, conforme procuravam por cacau, salsaparrilha, castanhas ou ovos de tartaruga, eles podiam passar por todo tipo de dificuldade - epidemias, ataques de povos indígenas, fome, motins ou a perda da canoa da aldeia e sua carga, para indicar apenas algumas. Ao retornarem, podiam encontrar suas famílias reduzidas à profunda pobreza ou doença, suas esposas tomadas por outros homens ou suas plantações abandonadas e devoradas por pestes (ROLLER, 2013, p. 203).

Este quadro de instabilidade na terra foi um freio para o desenvolvimento de estruturas autônomas de produção que favorecessem decisões sobre alocação de trabalho familiar, de tipo e momentos de cultivo, e muito restritamente lhes foi facultada a troca dos produtos da roça (RAVENA, 1994, p. 18). Fato é que, embora os indígenas fossem considerados livres a partir da Lei 1755, ainda assim tinham obrigação de trabalhar pois o Diretório de 1757 "Ihes atribui um lugar claramente determinado naquele que era considerado o mais importante e útil negócio dos estados do Pará e do Maranhão: o comércio do sertão” (DIAS, 2019, p. 246).

Em meio a esse cenário de conflito havia, também, os intermediários, que se constituíram uma frente protecionista formada pelos: 
indivíduos que no período anterior a 1750 - isto é, num período em que ainda não existiam as leis de proteção dos índios acima mencionadas e quando não era respeitada a legislação que sobre estas matérias anteriormente se tinha publicado (por exemplo, a lei de 1 de Outubro de 1680) - faziam a ligação entre a sociedade colonial paraense e as sociedades ameríndias dos sertões amazónicos. Ou seja, as mesmas pessoas que estavam profundamente envolvidas no comércio das drogas do sertão e, sobretudo, no tráfico de mão de obra escrava, e que alimentavam uma dinâmica social e económica que ligava o interior (e os seus sertões) ao litoral (e aos núcleos urbanos constituídos pelas cidades e povoações em seu redor) (DOMINGUES, 2019, p. 136).

Sommer (2005) propõe que, devido ao poder que os intermediários detinham através de tratados e alianças, quer pelo uso da força ou não, esses detinham certa notoriedade sobre diversos grupos indígenas, assim como influenciavam amplos estratos da sociedade paraense, tendo em vista que os mesmos proviam a mão de obra indígena, fazendo-se poderosos tanto nos sertões amazônicos como na sociedade colonial desse Estado, sendo financiados e apoiados pela elite, enriquecendo com os descimentos de índios em capturas ilegais e forçadas para o mercado das drogas do sertão.

Têm-se, ainda, a preocupação do governador Mendonça Furtado, um crítico agudo do chamado "dever educativo" dos jesuítas, com os episódios das fugas dos índios, que se revela em sentido duplo. Se, por um lado, a propriedade, a educação e a civilização do trabalho estavam sendo ameaçadas pelas constantes fugas e ocultamentos dos índios nos matos, por outro lado, a economia do Estado estava sendo envolvida plenamente pelo comércio das Religiões. Havia muito que o governador pombalino deixara de acreditar nas obras de catequese e educação empreendidas pelos missionários.

Em que pese a grande figura política de Mendonça Furtado, que é em si mesma um objeto de estudo para a compreensão da política pombalina, faz-se necessário duvidar do teor de suas acusações feitas em suas cartas aos jesuítas como principais "inspiradores" das fugas dos índios. Esta tese era bastante cômoda para os pombalinos - e será também muito cômoda para o historiador - pois, como se sabe, a necessidade de acusar "o inimigo comum", ou o "Corpo Poderoso", como Mendonça Furtado intitulava os jesuítas, já era uma vontade antecipada para o estigma da ameaça e da culpabilidade.

Na segunda metade do século XVIII, cerca de 65 índios foram trazidos de diferentes aldeias para auxiliar na carpintaria das construções das canoas. Não obstante, os índios foram fugindo paulatinamente. Desses 65 indígenas, sessenta eram da Companhia de Jesus, apenas um índio seria da aldeia dos capuchos e os outros seriam alforriados. Com as 
fugas em massa, estava instalada a desordem, consequentemente o atraso nas construções das embarcações. Ao solicitar que fossem atrás desses desertores, só trouxeram quinze, os demais já tinham se evadido para outras áreas da região, que de certo modo, eram conhecidas dos próprios índios (GUZMÁN; RAIOL JÚNIOR, 2019, p. 192).

Os índios e, mais ainda, a existência dos mocambos são demasiado complexos para serem atribuídos apenas às ações dos jesuítas - não que estes não fossem habilidosos o bastante para tal empreendimento. Mas, principalmente, porque o impulso originário, do qual resultaram as ações dos mocambos, deveuse firmemente ao domínio de sua autonomia, isto é, pela atitude de natureza independente desses sujeitos. Para Sampaio (2003):

o que se pode perceber claramente é que o projeto de civilização pombalino foi modificado por conta das condições coloniais de sua aplicação e pela intervenção direta dos personagens desse mundo, fossem considerados como agentes de execução, fossem vistos como objetos dessas intervenções civilizadoras. (SAMPAIO, 2003, p. 91).

Cremos ser correto afirmar que a existência e manifestação dos mocambos - como um corpo estranho na sociedade colonial, lutando pelo domínio de terras, com ação produtiva e como fenômeno social e cultural, com laços de resistência e solidariedade, dirigidas como um todo a um novo âmbito de vida coletiva - correspondem à expansão de um mundo paralelo e pleno de especificidades em relação a uma sociedade diferente e com valores antagônicos. Pode-se notar que essa incidência intermitente de "gente fugida" (os índios) contraria em múltiplos aspectos os objetivos do governo. Vemos assim, em sua origem e natureza, os mocambos de índios representarem um comportamento social, não isolado, de um mundo infenso, que não quer se sujeitar a um determinado universo material e espiritual com manifestações assumindo formas ousadas. Talvez o exemplo mais notável tenha ocorrido em Santa Ana de Macapá, no rio Maraquena, onde, em 15 de abril de 1752, o padre Inácio José Pantoja, relatou uma organização com produção economicamente autônoma pois nos lotes onde viviam os índios havia roças produtivas que poderiam abastecer "as monições das Prassas de Macapá com menos depezas de que se faz hoje da Fazenda Real" (CÓDICES DO ARQUIVO PÚBLICO DO PARÁ, [1769], doc. 13).

É assim que as próprias autoridades locais (militares, religiosos e políticos fiéis ao Marquês de Pombal) preocuparam-se com o domínio da ordem estável da sociedade em relação à desagregação dos valores e das relações morais e sociais das aldeias e vilas. O governo, sobre todos os assuntos que discorria internamente, parece referir-se literal e sub-repticiamente a um confronto com a existência e os 
efeitos da atividade daqueles que não mais se introduzem nos quadros da ordem colonial e que se incorporam em fugas e mocambos. Cabe ressaltar que uma característica delineadora desta população subalterna, tanto a população indígena em aldeias como a dos mocambos, é a sua ferrenha vontade de sobrevivência e resistência cultural, dado que "os índios não se sujeitavam pacificamente a qualquer dominação” (GUZMÁN; RAIOL JÚNIOR, 2019, p. 199).

Ao analisar as fontes históricas referentes ao assunto indígena, foi possível compreender as diferentes formas em que se davam as ações dos índios. As mais comuns foram as evasões para as matas, além das negociações e das alianças que comumente os índios faziam. Outro aspecto que também refletia a atividade indígena foi o embate, por meio do qual os índios lutavam em prol de si ou de grupos étnicos. Mas, não é de modo geral que essas ações se mostravam de maneira clara, muitas dessas atuações se apresentavam de forma "velada" ou "sutil". (GUZMÁN; RAIOL JÚNIOR, 2019, p. 198).

Portanto, nativos e pobres trabalhadores foram atores sociais que também impulsionaram política e economicamente a região, construindo os cenários que viriam a compor e formar o estado do Grão-Pará e Maranhão.

[...] Podemos observar o complexo e delicado universo de relações e jogos de poder existentes no estado do Grão-Pará e Maranhão na temporalidade em questão, onde os principais sujeitos - ordens religiosas, clérigos seculares, autoridades locais e metropolitanas, colonos/moradores e ameríndios Principais, demais aldeados e arredios - criavam suas teias de interesses no campo das relações interpessoais, para poderem exercer suas relações de dominação e subordinação no âmago daquele mosaico social emergente (RIBEIRO; PONTE, 2017, p. 113).

Por estes motivos, as categorias indios ou europeus, dominados ou dominantes - e acrescenta-se aqui, governo ou religiosos - são simplórias para descrever a complexidade das relações de poder que se estabeleceram nos conflitos que cercam a formação deste Estado e que se estabeleceram nos sertões amazônicos deste período (SOMMER, 2005). Abrangendo os mais diversos autores que vêm aos poucos sendo evidenciados na historiografia deste Estado e destacando sua formação como cada vez mais diversa e complexa.

\section{CONCLUSÃO}

À luz das reflexões sobre as origens do Estado do Grão-Pará e Maranhão, podemos afirmar que este processo se assentou sobre ações governamentais de três eixos: o povoamento da região com ações cujo escopo era a interiorização 
a partir de expedições de captura de trabalhadores indígenas, livres ou escravos, a serem utilizados em diferentes contextos, mesmo antes e durante o escravizamento de negros; a reorganização dos territórios em "lugares" ou "vilas" que passam a ser denominadas com nomes de cidades portuguesas; o estímulo à agricultura e ao comércio para potencializar a economia da região que já vinha englobando esforços desde períodos pré-pombalino; e controle direto do Estado, que se derivou de uma conturbada relação entre os governantes, religiosos, intermediários, índios e indivíduos de mocambos, em especial no que diz respeito ao controle do trabalho indígena, que era o centro da disputa entre colonos e missionários, e se prolongou até a posse do Marquês de Pombal, em torno de 1750, cuja política de exploração do território teve como consequência a expulsão dos jesuítas de Portugal e dos seus domínios.

Ressaltando-se a complexidade dessas conexões e a necessidade de uma compreensão em torno de suas transformações, permanências e desintegrações do período pré-pombalino ao pombalino, que enfatizam um Estado não de periferia - por se constituir "separado" do Estado do Brasil - mas como lugar de fundamental importância e relação constante com o seu Estado vizinho.

O processo de ascendência desse Estado demonstra a desorganização do trabalho nas aldeias e a própria sustentação dos religiosos no mercado de gêneros, em grande parte pelos anos de isenção fiscal e autoridade por parte do Estado nas atividades econômicas, o qual, ao tentar tornar-se majoritário, inicia uma disputa acirrada de controle das aldeias com os intermediários e religiosos, cujo verdadeiro pomo de discórdia, como vimos, não estava na extinção ou defesa da escravidão, mas no estabelecimento sobre quem exerceria o controle sobre o trabalho indígena.

Recorrendo à expulsão dos religiosos ou à segregação dos mesmos a atividades exclusivamente doutrinárias e catequistas, assim como a medidas que proclamavam a "liberdade dos índios" para sua política de territorialização e colonização, a Coroa abriu espaço para uma maior exploração do trabalho dos nativos, que se mostraram cada vez menos pacíficos em relação à colonização.

Esta disputa fez do Estado do Grão-Pará e Maranhão um Estado assentado na desterritorialização, escravização e corrupção, sempre em busca de um maior domínio português sobre a colônia. Mas também evidenciou um cenário formado por diversos atores que encontraram mecanismos de resistência à colonização, principalmente por parte dos indígenas, em que diversos grupos formaram uma sociedade colonial heterogênea e deram novos e particulares sentidos para a formação desse Estado, dessa Amazônia - e por que não falar em Amazônias? Indicando que a formação do Estado do Grão-Pará e Maranhão se constituiu um 
processo que se mostra cada vez complexo e rico nos estudos historiográficos que se preocupam no estudo de não uma, mas de muitas Amazônias.

De fato, o governo pombalino se constituiu em um divisor de águas no cenário de colonização mas, diferentemente de uma ruptura nas relações de dominação, tratou-se mais de uma permanência - com destaque para o cultivo da terra e o investimento na agricultura, além da doutrinação eurocêntrica dos nativos e seus territórios - por meio de medidas que buscavam reestruturar o estado e a Amazônia portuguesa ainda fundadas em culturas e territórios ancestrais; o que pode ter se constituído em forte empecilho para a concretização do ideal de criação do "novo estado" idealizado por Mendonça Furtado.

\section{REFERÊNCIAS}

AVELLAR, H. A. História administrativa e econômica do Brasil. Rio de Janeiro: Fename, 1970.

BEOZZO, J. O. Leis e regimentos das missões: política indigenista no Brasil. São Paulo: Loyola, 1983.

BERGER, M. Educação e dependência. São Paulo: DIFEL, 1984.

CAEIRO, J. Sobre o exílio das províncias transmarinas da Assistência portuguesa da Companhia de Jesus durante o Ministério do Marques de Pombal. Baía: Academia Brasileira de Letras, 1936.

CÓDICES DO ARQUIVO PÚBLICO DO PARÁ no 01. Belém: Arquivo Público do Estado do Pará, [1769].

COLLECÇÃO DA LEGISLAÇÃO PORTUGUEZA desde a ultima compilação das ordenações, do Desembargador Antonio Delgado da Silva pelo mesmo: Anno de 1750 a 1762. Lisboa: Typ. de Luiz Correa da Cunha, 1829.

COSTA, P. M. C. De mãos dadas pela foz do rio Amazonas: vilas e povoamentos na costa setentrional do Grão-Pará na segunda metade do século XVIII. Escritas do Tempo, Marabá, v. 1, n. 1, p. 117-139, 2019.

DIAS, M. N. Fomento e mercantilismo: a companhia geral do Grão-Pará e Maranhão (1755- 1778). Belém: UFPA, 1970.

DIAS, C. L. Os índios, a Amazônia e os conceitos de escravidão e liberdade. Estudos Avançados, São Paulo, v. 33, n. 97, p. 235-252, 2019.

DIAS, C. L.; BOMBARDI, F. A.; COSTA, E. G. Dimensão da população indígena incorporada ao estado do maranhão e grão-pará entre 1680 e 1750: uma ordem de grandeza. Revista de História, São Paulo, n. 179, a08619, 2020. 
DIRECTORIO que se deve observar nas Povoações dos Índios do Pará, e Maranhão em quanto Sua Magestade não mandar o contrario. In: COLLECÇÃO DA LEGISLAÇÃO PORTUGUEZA desde a ultima compilação das ordenações, do Desembargador Antonio Delgado da Silva. Pelo mesmo Anno de 1750 a 1762. Lisboa: Typ. de Luiz Correa da Cunha, 1829. Não paginado.

DOMINGUES, A. Sem medo de deus ou das justiças: os poderosos do sertão e o discurso colonial de Francisco Xavier de Mendonça Furtado para os indígenas do Grão-Pará (segunda metade do século XVIII). In: DOMINGUES, A.; RESENDE, M. L. C.; CARDIM, P. (org.). Os indígenas e as justiças no mundo ibero-americano (Sécs. XVI-XIX). Lisboa: CHAM, 2019. p. 129-155.

GOMES, F. S. O “campo negro” de Iguaçu: Escravos, camponeses e mocambos no Rio de Janeiro (1812-1883). Revista Estudos Afro-Asiáticos, Rio de Janeiro, v. 25, p. 43-72, 1993.

GUZMÁN, D. A.; RAIOL JUNIOR, L. A reorganização e a fluidez do uso da mão de obra indígena no Grão-Pará: segunda metade do século XVIII (17501765). Tellus, Campo Grandes, ano 19, n. 39, p. 177-205, 2019.

LAPA, J. R. A. Livro da visitação do Santo Ofício da Inquisição ao Estado do Grão-Pará (1763-1769). Petrópolis: Vozes, 1978.

LEITE, S. História da Companhia de Jesus no Brasil. Lisboa: Livraria Portugália, 1943.

LINHARES, M. Y. L. (org.). História geral do Brasil. Rio de Janeiro: Campus, 1990.

MAURO, F. (coord.). O Império luso-brasileiro (1620-1750): nova história da expansão portuguesa. Lisboa: Estampa, 1991. t. VII.

MAXWELL, K. R. A devassa da devassa: a inconfidência mineira - BrasilPortugal - 1750- 1808. Rio de janeiro: Paz e Terra, 1995.

MENDONÇA FURTADO, M. C. (ed.). A Amazônia na era pombalina: correspondência inédita do governador e capitão-general do Estado do GrãoPará e Maranhão Francisco Xavier de Mendonça Furtado, 1751-1759. Rio de Janeiro: Instituto Histórico e Geográfico Brasileiro, 1963. 3 tomos.

MOREIRA NETO, C. A. Índios da Amazônia: de maioria a minoria (1750-1850). Petrópolis: Vozes, 1988.

NOVAIS, F. Portugal e Brasil na crise do antigo sistema colonial (17771808). São Paulo: Hucitec, 1983. 
OLIVEIRA, R. L. O Estado do Grão-Pará e Maranhão na nova ordem política pombalina: a companhia geral do Grão-Pará e Maranhão e o diretório dos índios (1755-1757). Almanack Braziliense, São Paulo, v. 3, p. 124-134, 2006.

RAVENA, N. Abastecimento: falta, escassez do "pão ordinário” em vilas e aldeias do Grão- Pará. 1994. Dissertação (Mestrado em Planejamento do Desenvolvimento) - Núcleo de Altos Estudos Amazônicos, Universidade Federal do Pará, Belém, 1994.

RIBEIRO, B. E.; PONTE, V. S. Por uma história dos índios no Grão-Pará: estratégias, dinâmicas e protagonismos indígenas no contexto do Diretório Pombalino (1757-1798). Resgate: revista interdisciplinar de cultura, Campinas, v. 25, n. 1, p. 111-134, 2017.

ROCHA, R. A. Aldeamentos missionários no estado do Maranhão e Grão-Pará (1700-1750). Revista Habitus: revista do instituto goiano de pré-história e antropologia, Goiânia, v. 17, n. 2, p. 379-393, 2020.

ROLLER, H. F. Expedições coloniais de coleta e a busca por oportunidades no sertão amazônico, c. 1750-1800. In: Revista de História, São Paulo, n. 168, p. 201-243, 2013.

SAMPAIO, P. M. Cidades desaparecidas na Amazônia portuguesa: poiares, séculos XVIII e XIX. História Social, São Paulo, n. 10, p. 73-100, 2003.

SANTOS, F. V. O governo das conquistas do Norte: Trajetórias

administrativas no Estado do Grão-Pará e Maranhão (1751-1780). 2008. Tese (Doutorado em História Social) - Faculdade de Filosofia, Letras e Ciências Humanas, Programa de Pós-Graduação em História Social, Universidade de São Paulo, São Paulo, 2008.

SOMMER, B. Colony of the Sertão: Amazon Expeditions and the Indian Slave Trade. The Americas, [s. l.], v. 61, n. 3, p. 401-428, 2005.

SOUZA JUNIOR, J. A. A Companhia de Jesus e a questão da escravidão de índios e negros. Revista Eletrônica do Arquivo Público do Estado de São Paulo, São Paulo, n. 55, ago. 2012. Disponível em: http://www.historica. arquivoestado.sp.gov.br/materias/materia03/. Acesso em: 10 jun. 2021.

VIEIRA, A. Escritos instrumentais sobre os índios. São Paulo: EDUC, 1992. 
